Effects of Mandatory Military Service on Wages and Other Socioeconomic Outcomes

Patrick A. Puhani and Margret K. Sterrenberg

May 2021 Discussion Paper no. 2021-05

School of Economics and Political Science, Department of Economics 
Editor:

Publisher:
Mirela Keuschnigg

University of St.Gallen

School of Economics and Political Science

Department of Economics

Müller-Friedberg-Strasse 6/8

$\mathrm{CH}-9000$ St.Gallen

Email seps@unisg.ch

School of Economics and Political Science

Department of Economics

University of St.Gallen

Müller-Friedberg-Strasse 6/8

$\mathrm{CH}-9000$ St.Gallen

Electronic Publication:

http://www.seps.unisg.ch 


\title{
Effects of Mandatory Military Service on Wages and Other Socioeconomic Outcomes ${ }^{1}$
}

\author{
Patrick A. Puhani and Margret K. Sterrenberg
}

Corresponding author's
address:

\footnotetext{
1 We thank Wolfgang Meyer, Maresa Sprietsma, Stephan L. Thomsen and anonymous referees for helpful comments. This paper was supported by the German Research Foundation (Deutsche Forschungsgemeinschaft, DFG) under the DFG Priority Program 1646, Education as a Lifelong Process. The analysis is based on data from the National Educational Panel Study (NEPS): Starting Cohort 6 - Adults, doi:10.5157/NEPS:SC6:1.0.0. From 2008 to 2013, these NEPS data were collected as part of the Framework Program for the Promotion of Empirical Educational Research funded by the German Federal Ministry of Education and Research (BMBF). Since 2014, the NEPS survey has been carried out by the Leibniz Institute for Educational Trajectories (LlfBi) at the University of Bamberg in cooperation with a nationwide network.
} 


\begin{abstract}
In this paper, we estimate the effects of mandatory military service by exploiting the post-cold war decrease in the need for soldiers causing a substantial number of potential conscripts not to be drafted into the German military. Specifically, using previously unavailable information on degree of fitness in the military's medical exam as a control variable, we test for the effects of mandatory military service on wages; employment; marriage/partnership status; and satisfaction with work, financial situation, health, family life, friends, and life in general. We find almost no statistically significant effects of this 6 to 9 month career interruption for young German men, with the exception of hourly wage, which shows a negative point estimate of -15 percent with a large confidence interval of between -30 and -0.2 percent. This interval estimate is consistent with previous findings for the United States, Denmark, and the Netherlands.
\end{abstract}

\title{
Keywords
}

Career breaks, conscription, wages, employment, life satisfaction, natural experiment

\section{JEL Classification}

$\mathrm{J} 12, \mathrm{~J} 24, \mathrm{~J} 47$ 


\section{Introduction}

Mandatory military service (also known as conscription or the draft) has been widespread in industrialized countries even in the post-World War II period, although it has seen a significant decline since, with most North American and European countries moving to professional armies. Conscription ended in Britain in 1960, in the United States in 1973, in France in 2001, and in Germany in 2011. Despite of a decline in the use of conscription over the last decades, it is still in use, also in some highlydeveloped economies (Tarabar and Hall, 2016). Across the world, however, 94 of the 179 countries for which data are available still practice conscription (Galiani, Rossi, and Schargrodsky, 2011).

One consequence of conscription is that by levying a tax in kind through involuntary labor, it imposes costs on the participants that are not accounted for in national budgets (Oi, 1967). It also imposes a career break for those affected, which may have negative long-run effects on labor market outcomes. That is, women's early career breaks for childbirth lead to between-gender differences in the timing of work experience accumulation that account for 12 percent of the gender wage gap (Light and Ureta, 1995). It is thus worth asking whether, analogously, the interruption in education and work experience caused by conscription also has a negative effect on male wages.

In this paper, we investigate this possibility by estimating the effects of mandatory military service in Germany using an identification strategy that exploits the results of medical exams carried out by the military. These test results, although key to whether a youth is drafted or not, are seldom included in socioeconomic surveys and generally unavailable as administrative data. Their availability through our NEPS data source thus offers an exceptional opportunity not open to any of the studies reviewed below, none of which could use such information in their identification strategies. Specifically, we draw on the previous literature on the development of the German army (Tobiassen, 2001, 2005), which documents the reduced demand for conscripts after the fall of the Iron Curtain. As a result, we consider (not) being drafted conditionally on having completed the 
secondary schooling track and satisfactorily undergone the military exam to be almost random.

By applying this strategy to the complete sample, we produce confidence interval estimates indicating that compulsory military service has an effect on conscripts' post-service hourly wages of between -20 and +4 percent and between -30 and -0.2 percent for the subsample of men born 1970-1984 and 1976-1984, respectively. Both estimates control for actual work experience. Admittedly, because of the small sample size, these confidence intervals are large, and only the second is associated with a point estimate significantly different from zero. Nevertheless, these intervals mirror previous instrumental variable estimates reported for the U.S. by Angrist (1990), and Angrist, Chen, and Song (2011), for the Netherlands by Imbens and van der Klaauw (1995) and Hubers and Webbink (2015), and for Denmark by Bingley, Lundborg, and Lyk-Jensen (2020). Mouganie (2020) finds no significant estimates for France, but some point estimates for wages for high socio-economic status (SES) men are -4.8 and -2.7 percent despite significantly positive effects on education for this group, which can be explained by conscription deferral.

Most of the recent literature evaluating the effects of mandatory military service is microeconomic, employing natural experiments to evaluate the effect of mandatory military service on wages and other outcomes like employment, completed education, health or crime. One exception is the macro-level study by Keller, Poutvaara, and Wagner (2009), who use country fixed-effects regressions for 21 industrialized countries to show that conscription-measured as a binary indicator for the length of conscription and the share of conscripts in the labor force-is negatively associated with both GDP levels and GDP growth. Similarly, Lau, Poutvaara, and Wagener (2004) use a calibrated general equilibrium model to demonstrate that the draft may lower GDP not only through direct allocative inefficiencies but also indirectly through dynamic effects arising from less human capital accumulation and less physical capital accumulation through lower savings. Similar arguments are outlined theoretically in Poutvaara and Wagner (2007), whose authors argue that collecting taxes to run an allvolunteer army creates fewer economic distortions than the draft. 
On the microeconomic level, Angrist (1990) uses the Vietnam draft lottery as an instrumental variable for service in the U.S. army during the Vietnam war, which involved a median service length of 37 months and potential exposure to combat. The author finds a 15 percent reduction in earnings 10 years after service for white males (i.e., at around age 30), which amounts to a loss of about 2 years of work experience, somewhat less than the median length of military service. By age 50, however, the negative wage differential between veterans and nonveterans has disappeared. In an update using richer data sets, Angrist, Chen, and Song (2011) essentially confirm previous results but find that wages for veterans and nonveterans of the Vietnam war actually converge by age 40 . For a peacetime conscription of 14 months in the Netherlands (versus 37 months in Vietnam), Imbens and van der Klaauw (1995) find a 5 percent reduction in annual earnings 10 years after service using "special exemptions granted" and "proportion served" by cohort as instrumental variables.

These negative estimates for wage effects of compulsory military service in the U.S. and Netherlands, however, contrast with findings for Germany, Portugal, and the U.K. For example, Bauer et al. (2012) use a regression discontinuity design to exploit the 1955 reintroduction of the draft in Germany. While admitting that their regression discontinuity estimates are not very precise, having a standard error of $0.29 \log$ points on a point estimate of $0.09 \log$ points, they detect no statistically significant effect of mandatory military service on lifetime earnings, lifetime daily wage, or lifetime days of employment. Likewise, Paloyo (2010), applying a difference-in-differences approach with women as the comparison group to this same natural experiment, detects no significant effects of compulsory military service on log average daily wages.

Grenet, Hart, and Roberts (2011) exploit a similar natural experiment, the 1960 abolishment of conscription in the UK. They apply a regression discontinuity design to cohorts born in 1940 or after, who were not drafted. The authors find no effects of compulsory military service on log hourly earnings. With a point estimate of $0.034 \log$ points and a standard error of $0.035 \log$ points, they argue that their small and insignificant estimates might be explained by the fact that in the $1950 \mathrm{~s} / 60 \mathrm{~s}$, most conscripts received little education or training in civilian life, leaving school mostly at age 14 or 15 . 
Military conscription might thus have had two opposing and neutralizing effects: the positive effect of providing some training and the negative effect of lost work experience in the civilian labor market.

This hypothesis is reflected in the findings of Card and Cardoso (2012) for Portugal: for low-skilled conscripts born in 1967, they find an increase in log hourly wages of about 4 percent for the 2002-2009 period, which is statistically significant in the difference-in-differences estimates. It should be noted, however, that the low-skilled workers in this study had a maximum of only 4 years of education. Given Portugal's late return to democracy in 1975, the situation analyzed might thus have resembled that in Germany or the UK a few years after World War II. Moreover, when they consider all conscripts, the authors detect no statistically significant wage effects of compulsory military service in Portugal. ${ }^{1}$

Our paper is structured as follows: Section 2 describes key features of Germany's mandatory military service up until 2011. Section 3 describes our unique data source, which contains the outcome of the military's medical exam. Section 4 reports the regression estimates of mandatory military service's effects on wages, employment, and marriage/partnership status, as well as on indicators of satisfaction with various aspects of life. Section 5 concludes the paper.

\section{Mandatory Military Service in Germany}

Germany's post-war military was based on conscription, which was effectively abolished in 2011. After the 1989 fall of the Iron Curtain, the German military's demand for conscripts decreased much faster than the supply, so an increasing number of young men available for military service were not drafted (see Tobiassen, 2001, 2005, for a discussion of this situation's effect on 1970-1982 birth cohorts). In Fig, 1, we borrow data from Tobiassen $(2001,2005)$ to illustrate the share of young men in the 1970-1983 birth cohorts who (i) served in the military, (ii) performed alternative community service, or (iii) did not serve because they were not drafted or

1 There is also a literature on the effects of military service on education, crime, and health, which we do not review here. 
were deemed medically unfit. As the figure shows, whereas the share of men not serving is around 30 percent for the earlier cohorts, it increases steadily from the 1976 birth cohort onward to reach over 60 percent for the 1983 cohort.

In this paper, we regard (not) being drafted conditional on age, schooling, and medical exam result as an almost random event that we exploit to estimate the effects of peacetime military service on the labor market and family-related outcomes. As documented in Tobiassen (2001) and illustrated in Fig. 1, a 1995 reform of the military's medical exam procedure, together with the decreasing demand for soldiers, led to an increasing share of potential conscripts (i.e., men considered medically fit for service) born in 1976 and after not being drafted. For this reason, we also present separate estimates for cohorts born before and after 1976.

Most young men (around 90 percent according to our data) had to appear for the military's medical exam while in high school or in the apprenticeship system. This medical exam classified each individual into one of several degrees of fitness (Tauglichkeitsgrad), listed in Table 1. Only those in the three highest categories of fitness (T1, fit for all activities; T2, fit but with restrictions for certain activities; and T3, fit with restrictions for basic training and certain activities) were considered ready for drafting although not necessarily drafted (about 21 percent according to our data). ${ }^{2}$ Those in the T4 category, temporarily unfit, could be reexamined later, but those in the T5 category were considered unfit for service and so not drafted into either the military or the community service alternative.

To ensure that our study is built on a natural experiment in which (not) being drafted is almost random, we restrict our sample to young men with T1, T2, and T3 degrees of fitness. Because T3 is the lowest category, we expect this group to be the least attractive for the military and hence the least susceptible to being drafted. We thus use degree of fitness as a control variable in the regressions. Additionally, because anecdotal evidence, unreported regression estimates, and our sample means (Table 3) indicate that the German military was more likely to draft young men from the higher

2 In 1995, T7 was introduced to indicate that a young man could do some service for the army but not participate in basic training. However, since January 2001, men with this degree of fitness have no longer been drafted. T6 denotes reservists with a T3 degree of fitness. 
educational schooling track, we also control for the secondary schooling track. $^{3}$

In our main set of regressions, we further exclude young men who performed alternative community service instead of military service because the easiest way to be drafted into this alternative was to declare a wish not to serve in the military before the medical exam. Such a declaration was thought to make doctors less strict about the fitness criteria. Hence, we avoid potential endogeneity issues by excluding those who engaged in community service.

Draft age depended on schooling track (see Fig. A1 for the distribution): young men who had completed the highest track were usually drafted after high school at around age 19 or 20 . Those from the other tracks typically finished their apprenticeship training before being drafted at 20 or 21. Service duration was longer for earlier cohorts and then decreasing over time. Before the end of the cold war, the duration was 15 months, which was reduced to 12 months in 1990 and then lowered again to 10 months and 9 months in 1996 and 2000, respectively. The community service alternative usually lasted a few months longer than the military service (see Fig. 2 for durations over time). Conscripts also had the option, however, of signing up for a longer period of service, meaning that our "treatment" (mandatory military service) may have caused longer exposure to the military in several cases. Appendix Fig. A2, which plots the distribution of the number of months served in the military (censored at 30 months for presentational reasons), shows that a significant number of young men decided to stay in the military longer than required.

\section{Data}

We use data from Germany's recently created National Educational Panel Study (NEPS, see Blossfeld, Roßbach, and von Maurice, 2011, for a general description of this data set). For our purposes, we use Starting Cohort 6-Adults (Adult Education and Lifelong Learning), which contains self-

3 Apart from relying on formal education and its medical examination, the German military also carried out a test similar to the Armed Forces Qualification Test (AFQT) (Eignungstest). Unfortunately, these results are not included in our data. In fact, as far as we know, the exact results of this test, unlike those of the medical exam, were not even passed on to the examinees. 
reported retrospective information on the degree of fitness assigned in the military's medical exam and on mandatory military service participation, as well as labor market and demographic information. We derive our outcome variables using these data: wages, employment status, ever having been married, whether currently married or currently living in a partnership, and satisfaction with various aspects of life.

Table 2 outlines the sample selection process beginning with the NEPS Starting Cohort 6 of 2009/2010, which contains 11,649 observations, 5,714 of them male. Restricting our analysis to West German men, then reduces the sample size to 4,155 . The key variable for the natural experiment is the degree of fitness in the military's medical exam, which only applies to the cohorts born after 1970 (aged 26 to 40 at the time of interview). This restriction lowers the sample size to only 893 because when these cohorts were born, Germany was experiencing a low birth rate (see Appendix Fig. A3). These cohorts (especially those born after 1976) are the core of our natural experiment because a drastically decreasing demand for German military conscripts in the immediate post-cold war period (1990-2004) meant a high chance that these individuals would not be drafted (see Section 2).

In addition to restricting the sample to West German men aged 26 to $40(N=893)$, we must also restrict it to those classified as fit for service who have valid entries for the key variables. The result is 702 observations with available data on employment and marital/partnership status (see Table 2). Of these 702 observations, 678 have their fitness classification from the military's medical exam recorded, but only 654 meet the T1, T2, and T3 criterion for being drafted. ${ }^{4}$

As previously explained, we exclude those who did community rather than military service in case a request for such placement may have influenced the medical exam results. We are then left with 375 observations of whom 78 ( 21 percent) were not drafted into the military. It is these mendeemed fit for military service, not assigned to community service, but not

4 We exclude men with a T7 degree, not only because this category was not introduced until the mid-1990s but because as of 2001, T7 males were no longer drafted. The sample size is too small to use this reform in a regression discontinuity design strategy. 
all drafted - who make up the natural experiment for which we run our regressions.

Information on hourly wage, defined as gross monthly wage divided by actual or contract hours worked, is available for 290 of the 375 observations, of whom 266 are not self-employed. The sample means (using NEPS sampling weights) are displayed in Table 3, which clearly shows that those who completed military service (the treatment group) exhibit higher wages than those who did not serve in the military. On the other hand, these men are also older, more educated, and in a higher fitness category than those who did not serve. It is therefore unclear whether their higher wages, or their higher employment and marriage/partnership rates, are the result of their service in the military or their different socioeconomic background. The following section addresses these questions using regression analysis.

\section{$4 \quad$ Results}

We use ordinary least squares regression (OLS) to compare the log hourly wages, employment rates, indicators of ever having been or currently being married or living in a partnership, and indicators of satisfaction with various aspects of life of men who were drafted into the military versus those who were not. Our estimating equation is

$$
\begin{aligned}
(\text { outcome })_{i}= & \alpha+\tau(\text { treatment })_{i}+\beta\left(\text { degree }_{\text {fitness }}\right)_{i}+\gamma(\text { controls })_{i} \\
& +\varepsilon_{i}
\end{aligned}
$$

where outcome is the logarithm of the hourly wage or any of the other outcomes like employment or satisfaction with various aspects of life, treatment is participation in mandatory military service, the degree of fitness test result is a key control specified by dummy variables for T1 and T3 (with T2 as the base category), other controls are the educational schooling track, age, and work experience.

Table 4 reports the regression results for mandatory military service as treatment and the log hourly wage as the outcome variable, with control variables successively increased across the columns. That is, no control is 
included in column (1), but columns (2) and (3) add in age and education, respectively. In column (4), the degree of fitness is held constant (to exploit the natural experiment), while column (5) introduces a linear control for whether military service' potential effects can be explained through its effects on work experience. In this latter, because the age variable ranges only from 26 to 40 and is already controlled for in a second-order polynomial, we include no square of years of work experience.

Once control variables are added, the resulting point estimates suggest that military service reduces hourly wages by about 8.4 percent (column 4) and that this effect is not explained by differences in work experience between these two groups (comparing columns (4) and (5) in Table 4). However, the fact that the standard error for this 8.4 percent estimate is 6.3 percent indicates not only that the point estimate is not statistically significant but that a larger sample is needed to obtain a more precise estimate. Nevertheless, the other coefficients in the regression yield plausible values: a higher level of schooling is associated with higher wages, and the return to work experience for young workers ( 26 to 40 ) is 3.5 percent when age is held constant (column (5)). ${ }^{5}$

The estimation results with employment status as the outcome variable are presented in Table 5. Here, the point estimates for the specifications with control variables are positive but very small (around one percentage point). With a standard error of around 5 percentage points, no point estimate is statistically significant. In fact, few variables in these regressions are significant, although higher age and higher education generally improve employability. Not surprisingly, as column (5) shows, past work experience is a predictor of current employment.

For the outcome "ever married" (Table 6), the estimated treatment effects are so close to zero that they do not even reach one percentage point. The standard errors are as high as 8 percentage points, so again none of the small estimated treatment effects is statistically significant. Once more, however, the coefficient estimates for other variables are plausible: the probability of ever having been married rises with age, and work experience

5 Note that returns to experience are highest at the beginning of a person's career (Heckman, Lochner, and Todd, 2006, p. 321ff.), which explains this comparatively large estimate, given that we only observe young workers. 
seems to be an even better predictor of being "marriageable" than age (comparing column (4) with column (5)). Men assigned the highest degree of fitness on the medical exam (T1) are 12 percentage points more likely to be married than men assigned the second highest degree of fitness (T2), but a standard error of 8 percentage points makes this estimate statistically marginally insignificant.

Apart from an indicator for ever having been married, our data also include indicators for whether a man is currently married or currently lives in a partnership (married or not married). The regression results with this variable as an outcome are reported in Table 7 and 8 . Although none of the estimates of the mandatory military service coefficient are statistically significant, the point estimates in columns (4) and (5) in Table 7 (i.e., the estimates for currently being married) amount to a positive 10 percent.

Because the NEPS data include indicators of satisfaction with various aspects of life, we provide estimates using these aspects as outcome variables (see Table 9). After normalizing the indicators' original Likert scaling to a range between 0 and 1 , we are able to assess satisfaction with (1) life in general, (2) work, (3) financial situation, (4) health, (5) family, and (6) friends. Table 8 reports the regression results for the full specification, which contains all control variables including years of work experience. As suggested by the sample means in Table 3 , in all cases, the satisfaction indicators are on average 70 percent or higher. The point estimates of mandatory military service's effects on any of the satisfaction indicators are 5.5 percent at the maximum-5.5 percent for satisfaction with work and 5.1 percent for satisfaction with family life-but no estimate is statistically different from zero.

As yet, we have detected no statistically significant effects of mandatory military service on any of the outcome variables investigated: wages, employment, ever having been married, living in a partnership, and satisfaction with various aspects of life. Hence, in a further series of regressions, we produce separate estimates by birth cohort group (1970-1975 and 1976-1984) to take into account the 1995 reform of the military's medical exam combined with the decreasing demand for soldiers, which significantly raised the share of potential conscripts not being drafted in the 
post-1976 birth cohorts. This is why the cohorts born after 1976 are the core of our natural experiment.

Because splitting our sample by birth cohort group reduces sample size even further, almost none of these separate estimates is statistically significant. Hence, Table 10 only reports the results for log wage as the outcome variable, some of which are statistically significant. ${ }^{6}$ For the 1976 1984 birth cohorts, the point estimates suggest a reduction in hourly wage of 15.1 and 15.6 percent in the specifications where work experience is held constant versus not taken into account, respectively. Thus, taking work experience into account, the reduction in wages from participating in mandatory military service is diminished. The standard errors attached to these estimates are 7.6 and 7.8 percent, respectively, which makes both estimates statistically significant at the 5 percent level. It is also worth noting that the 1976-1984 cohorts are those affected by the 1995 medical exam reform, following which the not drafting of medically fit conscripts increased. The point estimates of negative hourly wage effects over 15 percent, with standard errors of over 7 percent, produce confidence intervals that mirror the smaller (albeit still significant) negative wage effect estimated by Angrist (1990) and Angrist, Chen, and Song (2011) for the U.S., by Imbens and van der Klaauw (1995) and Hubers and Webbink (2015) for the Netherlands, and by Bingley, Lundborg, and Lyk-Jensen (2020) for Denmark. These authors' point estimates were 3-5 percent for 8 months of service in Denmark or for 14 months of service in the Netherlands, and 15 percent for 37 months with the U.S. armed forces in Vietnam.

Because men committing to a longer period of service might have been more likely to be drafted in Germany and may be a selected group, we also reduce the sample to men who did not serve longer than 20 months in the military. The sample size in this case reduces from 148 to 130 in the last two columns of Table 10. The point estimates are still negative at over 13 percent and statistically significant at the 10 percent level with standard errors of 8 percentage points. ${ }^{7}$

6 The satisfaction with work and friends estimates are also significantly positive at 0.11 (significant at the 5 percent level) and at 0.05 (significant at the 10 percent level), respectively, for the 1976 to 1984 cohorts (not shown here). None of the other estimates for the 1976 to 1984 cohorts is statistically significant.

7 This robustness check was suggested by an anonymous referee. 
In sum, then, our results suggest that mandatory military service may have a negative effect on hourly wages, even when the loss of work experience incurred by military service is controlled for. A more precise claim, however, would require a larger sample size. On the other hand, the point estimates for the outcomes "employed" and "ever married" are close to zero and statistically insignificant, as are almost all the estimates for indicators of satisfaction with various aspects of life.

\section{Conclusions}

Using unique data on the German military's medical exam, this study examines the effect of mandatory military service on the hourly wage, employment, and marital and partnership status of 1970-1984 German birth cohorts, as well as their satisfaction with work, financial situation, health, family life, friends, and life in general. By exploiting the natural experiment that in the post-cold war period (and especially for post-1976 birth cohorts) not all potential conscripts were drafted (interpreted as almost random), and controlling for both medical exam results and lower school track, we identify barely any statistically significant effects of mandatory military service on the outcomes considered. One important exception is that birth cohorts born 1976 and after show statistically significant negative wage effects. Although the standard error is almost 8 percent, the point estimate suggests a wage reduction of about 15 to 16 percent, which is in a similar range as the statistically significant point estimates for the U.S. (Angrist, 1990; Angrist, Chen, and Song, 2011), Netherlands (Imbens and van der Klaauw, 1995), and Denmark (Bingley, Lundborg, and Lyk-Jensen, 2020).

Although our small sample size may have prevented the identification of significant effects overall, our findings do imply that in a developed economy with a competitive labor market, a career break through mandatory military service may have a negative wage effect for the average conscript, even when actual work experience is controlled for. This observation does not, however, mean that low-skilled men cannot benefit from military service, as did some Portuguese men with at most 4 years of schooling (Card and Cardoso, 2012). 


\section{References}

Angrist, J.D. (1990): Lifetime Earnings and the Vietnam Era Draft Lottery: Evidence from Social Security Administrative Records, American Economic Review 80: 313-336.

Angrist, J.D., S. Chen, and J. Song (2011): Long-Term Consequences of Vietnam-Era Conscription: New Estimates Using Social Security Data, American Economic Review Papers and Proceedings 101: 334-338.

Bauer, T.K., S. Bender, A.R. Paloyo, and C.M. Schmidt (2012): Evaluating the Labor-Market Effects of Compulsory Military Service, European Economic Review 56: 814-829.

BGBl (1990): Gesetz zur Regelung der Dauer des Grundwehrdienstes und des Zivildienstes vom 26.11.1990, Bundesgesetzblatt, Jahrgang 1990, Volume I, p. 2520, available at: http://www.bgbl.de

BGB1 (1994): Zweites Gesetz zur Änderung des Wehrpflichtgesetzes und des Zivildienstgesetzes vom 21.6.1994, Bundesgesetzblatt, Jahrgang 1994, Volume I, p. 1286, published June 28, 1994, available at: http://www.bgbl.de

BGBl (1995): Bekanntmachung der Neufassung des Wehrpflichtgesetzes vom 15.12.1995, Bundesgesetzblatt, Jahrgang 1995, Volume I, p. 1756, available at: http://www.bgbl.de

Bingley P., P. Lundborg, and S.V. Lyk-Jensen (2020): The Opportunity Costs of Mandatory Military Service: Evidence from a Draft Lottery, Journal of Labor Economics 38: 39-66.

Blossfeld, H.-P., H.-G. Roßbach, and J. von Maurice (eds.) (2011): Education as a Lifelong Process: The German National Educational Panel Study (NEPS), Zeitschrift für Erziehungswissenschaft: Special Issue 14.

Card. D. and A.R. Cardoso (2012): Can Compulsory Military Service Raise Civilian Wages? Evidence from the Peacetime Draft in Portugal, American Economic Journal: Applied Economics 2012, 4: 57-93.

Galiani, S., M.A. Rossi and E. Schargrodsky (2011): Conscription and Crime: Evidence from the Argentine Draft Lottery, American Economic Journal: Applied Economics 3: 119-36.

Grenet, J., R.A. Hart, J.E. Roberts (2011): Above and Beyond the Call. LongTerm Real Earnings Effects of British Male Military Conscription in the Post-War Years, Labour Economics 18: 194-204. 
Heckman, J.J., L.J. Lochner, and P.E. Todd (2006): Earnings Functions, Rates of Return and Treatment Effects: The Mincer Equation and Beyond, in Hanushek, E.A. and F. Welch (eds.): Handbook of the Economics of Education, Volume 1, 307-458, Amsterdam: NorthHolland.

Hubers, F. and D. Webbink (2015): The Long-Term Effects of Military Conscription on Educational Attainment and Wages, IZA Journal of Labor Economics 4: 1-16.

Imbens, G. and W. van der Klaauw (1995): Evaluating the Cost of Conscription in the Netherlands, Journal of Business \& Economic Statistics 13: 207-215.

Keller, K., Poutvaara, P. and A. Wagener (2009): Military Draft and Economic Growth in OECD Countries, Defence and Peace Economics 20: 373-393.

Lau, M.I., Poutvaara, P. and A. Wagener (2004): Dynamic Costs of the Draft, German Economic Review 5: 381-406.

Light, A. and M. Ureta (1995): Early-Career Work Experience and Gender Wage Differentials, Journal of Labor Economics 13(1): 121-154

Mouganie, P. (2020): Conscription and the Returns to Education: Evidence from a Regression Discontinuity, Scandinavian Journal of Economics 122: 1112-1139.

Oi, W. (1967): The Economic Cost of the Draft, American Economic Review Papers and Proceedings 57: 39-62.

Paloyo, A.R. (2010): Compulsory Military Service in Germany Revisited, Ruhr Economic Papers \#206, Bochum, Dortmund, Duisburg, Essen.

Poutvaara, P. and A. Wagener (2007): To Draft or Not to Draft: Inefficiency, Intergenerational Incidence, and Political Economy of Military Conscription, European Journal of Political Economy 23: 975-987.

Tarabar, D. and J.C. Hall (2016): Explaining the Worldwide Decline in the Length of Mandatory Military Service, 1970-2010, Public Choice 168: 55-74.

Tobiassen, P. (2001): Die Neuausrichtung der Bundeswehr und die Frage der Wehrgerechtigkeit - Eine umfassende Auswertung neuerer statistischer Angaben des Bundesministers der Verteidigung, zweite durchgesehene Auflage, Zentralstelle für Recht und Schutz der Kriegsdienstverweigerer aus Gewissensgründen e. V., Bremen. 
Tobiassen, P. (2005): Wehrgerechtigkeit 2005 - Eine umfassende Auswertung aktueller statistischer Angaben des Bundesministeriums der Verteidigung, Zentralstelle für Recht und Schutz der Kriegsdienstverweigerer aus Gewissensgründen e. V., Bremen. 


\section{Tables and Figures}

Table 1

Degrees of Fitness Assigned by the German Military

\begin{tabular}{ll}
\hline Abbreviation & Explanation \\
\hline T1 & Fit for all activities \\
T2 & Fit with restrictions for certain activities \\
T3 & Fit with restrictions for basic training and certain activities \\
& \\
T4 & Temporarily not fit for service or deferred \\
T5 & Not fit for service \\
T7 & Since 1995: fit for certain activities of basic service with \\
& exemption from basic training \\
\hline
\end{tabular}

Note: T6 also exists and is designated ex post to reservists with a T3 degree of fitness. Source: BGB1 (1995), Tobiassen (2001).

Table 2

Sample Selection

\begin{tabular}{lr}
\hline Sample & Observations \\
\hline NEPS SC6 2009/2010 full sample & 11,649 \\
Men only & 5,714 \\
West-German federal states excluding Berlin & 4,612 \\
German citizens (naturalized before age 20) & 4,155 \\
Age 24 to 64 & 3,975 \\
Age 26 to 40 at interview and born after 1970 & 893 \\
Fit for service & 702 \\
$\quad$ Information on marriage/partnership status, & 702 \\
employment & 701 \\
Information on education & 678 \\
Information on degree of fitness & 654 \\
Degree of fitness either T1, T2, or T3 & $\mathbf{3 7 5}$ \\
$\quad$ Military service (297) or not treated (78) & 375 \\
Satisfaction ${ }^{2}$ & 290 \\
Information on hourly wage & 266 \\
$\quad$ Not self-employed & \\
\hline Note: ${ }^{1}$ The NEPS only asked men born in 1970 or later for their degrees of fitness on the military \\
medical exam. \\
${ }^{2}$ There are 14 missing values in "satisfaction with work" and one missing value in "satisfaction with \\
family life." \\
${ }^{3}$ For the sample selected, there are 14\% missing observations in hourly wages because of missing \\
values in gross monthly wages or missing values in actual hours worked. We exclude eight \\
observations lower than the 0.5 centile or higher than the 99.5 centile either in the gross monthly \\
wages or in the hourly wages. \\
Source: NEPS Starting Cohort 6 - Adults, doi:10.5157/NEPS:SC6:1.0.0; own calculations. \\
$\quad$
\end{tabular}


Table 3

Weighted Sample Means

\begin{tabular}{|c|c|c|c|c|c|c|}
\hline & \multicolumn{2}{|c|}{ Fit for service } & \multicolumn{2}{|c|}{ Treated } & \multicolumn{2}{|c|}{ Not treated } \\
\hline & Obs. & Mean & Obs. & Mean & Obs. & Mean \\
\hline \multicolumn{7}{|l|}{ Outcome variables } \\
\hline Hourly wage & 290 & 16.07 & 236 & 16.31 & 54 & 15.18 \\
\hline Log hourly wage & 290 & 2.68 & 236 & 2.70 & 54 & 2.64 \\
\hline Employed & 375 & 0.90 & 297 & 0.91 & 78 & 0.86 \\
\hline Ever married & 375 & 0.61 & 297 & 0.63 & 78 & 0.54 \\
\hline Currently married & 375 & 0.58 & 297 & 0.61 & 78 & 0.48 \\
\hline Partnership & 375 & 0.87 & 297 & 0.88 & 78 & 0.85 \\
\hline \multicolumn{7}{|l|}{ Satisfaction with } \\
\hline Life in general & 375 & 0.77 & 297 & 0.78 & 78 & 0.76 \\
\hline Work & 361 & 0.74 & 290 & 0.75 & 71 & 0.69 \\
\hline Finances & 375 & 0.73 & 297 & 0.74 & 78 & 0.72 \\
\hline Health & 375 & 0.79 & 297 & 0.79 & 78 & 0.81 \\
\hline Family & 374 & 0.78 & 297 & 0.79 & 77 & 0.76 \\
\hline Friends & 375 & 0.82 & 297 & 0.82 & 78 & 0.82 \\
\hline Treated & 375 & 0.77 & 297 & 1.00 & 78 & 0.00 \\
\hline \multicolumn{7}{|l|}{ Control variables } \\
\hline Age & 375 & 32.25 & 297 & 32.84 & 78 & 30.26 \\
\hline Lower track & 375 & 0.24 & 297 & 0.25 & 78 & 0.22 \\
\hline Medium track & 375 & 0.36 & 297 & 0.33 & 78 & 0.48 \\
\hline Higher track & 375 & 0.12 & 297 & 0.13 & 78 & 0.08 \\
\hline Highest track & 375 & 0.28 & 297 & 0.29 & 78 & 0.22 \\
\hline Fitness T1 & 375 & 0.13 & 297 & 0.13 & 78 & 0.12 \\
\hline Fitness T2 & 375 & 0.68 & 297 & 0.73 & 78 & 0.54 \\
\hline Fitness T3 & 375 & 0.19 & 297 & 0.14 & 78 & 0.33 \\
\hline Work experience & 375 & 10.25 & 297 & 10.82 & 78 & 8.33 \\
\hline \multicolumn{7}{|c|}{$\begin{array}{l}\text { Note: The indicators of satisfaction with various aspects of life are normalized to lie between zero } \\
\text { and one. Treatment equals one if a man has served in the military and zero otherwise. The lowest } \\
\text { track corresponds to Hauptschule (usually } 9 \text { years of schooling), the medium track corresponds to } \\
\text { Realschule (10 years of schooling). The higher track corresponds to Fachhochschulreife which is } \\
\text { allows restricted access to tertiary education (for example restricted by subject) and is offered to } \\
\text { students who have first completed the medium track. The highest track corresponds to Gymnasium } \\
\text { (13 years of schooling). } \\
\text { Source: NEPS Starting Cohort } 6 \text { - Adults, doi:10.5157/NEPS:SC6:1.0.0; author calculations. }\end{array}$} \\
\hline
\end{tabular}


Table 4

Mandatory Military Service and Log Wages

\begin{tabular}{|c|c|c|c|c|c|}
\hline & (1) & (2) & (3) & (4) & (5) \\
\hline Treated & $\begin{array}{c}0.055 \\
(0.072)\end{array}$ & $\begin{array}{c}-0.045 \\
(0.063)\end{array}$ & $\begin{array}{c}-0.064 \\
(0.059)\end{array}$ & $\begin{array}{c}-0.084 \\
(0.063)\end{array}$ & $\begin{array}{l}-0.083 \\
(0.062)\end{array}$ \\
\hline Age & & $\begin{array}{c}0.029 * * * \\
(0.006)\end{array}$ & $\begin{array}{c}0.036^{* * *} * \\
(0.006)\end{array}$ & $\begin{array}{c}0.036^{* * *} \\
(0.006)\end{array}$ & $\begin{array}{c}0.003 \\
(0.010)\end{array}$ \\
\hline Age squared & & $\begin{array}{l}-0.003 \\
(0.002)\end{array}$ & $\begin{array}{l}-0.003 \\
(0.002)\end{array}$ & $\begin{array}{l}-0.003 \\
(0.002)\end{array}$ & $\begin{array}{c}-0.003 \\
(0.002)\end{array}$ \\
\hline Lower track & & & $\begin{array}{c}-0.242 * * * \\
(0.079)\end{array}$ & $\begin{array}{c}-0.238^{* * *} \\
(0.080)\end{array}$ & $\begin{array}{c}-0.257 * * * \\
(0.074)\end{array}$ \\
\hline Higher track & & & $\begin{array}{c}0.274 * * * \\
(0.069)\end{array}$ & $\begin{array}{c}0.271 * * * \\
(0.068)\end{array}$ & $\begin{array}{c}0.310 * * * \\
(0.072)\end{array}$ \\
\hline Highest track & & & $\begin{array}{c}0.179 * * * \\
(0.062)\end{array}$ & $\begin{array}{c}0.177 * * * \\
(0.063)\end{array}$ & $\begin{array}{c}0.264 * * * \\
(0.066)\end{array}$ \\
\hline Degree of fitness T1 & & & & $\begin{array}{c}-0.003 \\
(0.086)\end{array}$ & $\begin{array}{c}-0.018 \\
(0.081)\end{array}$ \\
\hline Degree of fitness $\mathrm{T} 3$ & & & & $\begin{array}{c}-0.072 \\
(0.087)\end{array}$ & $\begin{array}{l}-0.060 \\
(0.085)\end{array}$ \\
\hline Work experience & & & & & $\begin{array}{c}0.035 * * * \\
(0.008)\end{array}$ \\
\hline Constant & $\begin{array}{c}2.641 * * * \\
(0.064)\end{array}$ & $\begin{array}{c}2.788 * * * \\
(0.057)\end{array}$ & $\begin{array}{c}2.775 * * * \\
(0.062)\end{array}$ & $\begin{array}{c}2.805 * * * \\
(0.066)\end{array}$ & $\begin{array}{c}2.381 * * * \\
(0.128)\end{array}$ \\
\hline Observations & 290 & 290 & 290 & 290 & 290 \\
\hline R-squared & 0.003 & 0.094 & 0.248 & 0.252 & 0.298 \\
\hline
\end{tabular}

Note: The lowest track corresponds to Hauptschule (usually 9 years of schooling), the base category of the medium track corresponds to Realschule (10 years of schooling). The higher track corresponds to Fachhochschulreife which is allows restricted access to tertiary education (for example restricted by subject) and is offered to students who have first completed the medium track. The highest track corresponds to Gymnasium (13 years of schooling). Robust standard errors in parentheses; *** $\mathrm{p}<0.01, * * \mathrm{p}<0.05, * \mathrm{p}<0.1$

Source: NEPS Starting Cohort 6 - Adults, doi:10.5157/NEPS:SC6:1.0.0; author calculations. 
Table 5

Mandatory Military Service and Employment

\begin{tabular}{|c|c|c|c|c|c|}
\hline & (1) & (2) & (3) & (4) & (5) \\
\hline Treated & $\begin{array}{c}0.045 \\
(0.049)\end{array}$ & $\begin{array}{c}0.009 \\
(0.052)\end{array}$ & $\begin{array}{c}0.011 \\
(0.053)\end{array}$ & $\begin{array}{c}0.008 \\
(0.055)\end{array}$ & $\begin{array}{c}0.002 \\
(0.048)\end{array}$ \\
\hline Age & & $\begin{array}{c}0.013 * * * \\
(0.004)\end{array}$ & $\begin{array}{c}0.014 * * * \\
(0.004)\end{array}$ & $\begin{array}{c}0.015 * * * \\
(0.004)\end{array}$ & $\begin{array}{c}-0.020 * * * \\
(0.007)\end{array}$ \\
\hline Age squared & & $\begin{array}{c}-0.001 \\
(0.001)\end{array}$ & $\begin{array}{l}-0.000 \\
(0.001)\end{array}$ & $\begin{array}{l}-0.000 \\
(0.001)\end{array}$ & $\begin{array}{c}-0.001 \\
(0.001)\end{array}$ \\
\hline Lower track & & & $\begin{array}{c}-0.099 * \\
(0.058)\end{array}$ & $\begin{array}{l}-0.098^{*} \\
(0.059)\end{array}$ & $\begin{array}{l}-0.090 * \\
(0.052)\end{array}$ \\
\hline Medium track & & & $\begin{array}{l}-0.021 \\
(0.057)\end{array}$ & $\begin{array}{c}-0.019 \\
(0.055)\end{array}$ & $\begin{array}{c}0.044 \\
(0.050)\end{array}$ \\
\hline Highest track & & & $\begin{array}{c}0.004 \\
(0.042)\end{array}$ & $\begin{array}{c}0.008 \\
(0.042)\end{array}$ & $\begin{array}{c}0.097 * * \\
(0.046)\end{array}$ \\
\hline Degree of fitness T1 & & & & $\begin{array}{l}-0.051 \\
(0.059)\end{array}$ & $\begin{array}{c}-0.064 \\
(0.056)\end{array}$ \\
\hline Degree of fitness T3 & & & & $\begin{array}{c}-0.015 \\
(0.053)\end{array}$ & $\begin{array}{c}0.002 \\
(0.047)\end{array}$ \\
\hline Work experience & & & & & $\begin{array}{c}0.035 * * * \\
(0.007)\end{array}$ \\
\hline Constant & $\begin{array}{c}0.862 * * * \\
(0.045)\end{array}$ & $\begin{array}{c}0.910 * * * \\
(0.057)\end{array}$ & $\begin{array}{c}0.933 * * * \\
(0.053)\end{array}$ & $\begin{array}{c}0.942 * * * \\
(0.058)\end{array}$ & $\begin{array}{c}0.534 * * * \\
(0.099)\end{array}$ \\
\hline Observations & 375 & 375 & 375 & 375 & 375 \\
\hline R-squared & 0.004 & 0.038 & 0.057 & 0.060 & 0.184 \\
\hline
\end{tabular}


Table 6

Mandatory Military Service and Ever Having Been Married

\begin{tabular}{|c|c|c|c|c|c|}
\hline & (1) & (2) & (3) & (4) & (5) \\
\hline Treated & $\begin{array}{c}0.088 \\
(0.074)\end{array}$ & $\begin{array}{c}-0.007 \\
(0.077)\end{array}$ & $\begin{array}{c}-0.003 \\
(0.077)\end{array}$ & $\begin{array}{c}0.006 \\
(0.078)\end{array}$ & $\begin{array}{c}0.003 \\
(0.077)\end{array}$ \\
\hline Age & & $\begin{array}{c}0.037 * * * \\
(0.006)\end{array}$ & $\begin{array}{c}0.037 * * * \\
(0.006)\end{array}$ & $\begin{array}{c}0.037 * * * \\
(0.006)\end{array}$ & $\begin{array}{c}0.014 \\
(0.011)\end{array}$ \\
\hline Age squared & & $\begin{array}{c}0.000 \\
(0.002)\end{array}$ & $\begin{array}{c}0.000 \\
(0.002)\end{array}$ & $\begin{array}{c}0.000 \\
(0.002)\end{array}$ & $\begin{array}{l}-0.000 \\
(0.002)\end{array}$ \\
\hline Lower track & & & $\begin{array}{c}-0.051 \\
(0.083)\end{array}$ & $\begin{array}{c}-0.052 \\
(0.082)\end{array}$ & $\begin{array}{c}-0.046 \\
(0.081)\end{array}$ \\
\hline Medium track & & & $\begin{array}{l}-0.029 \\
(0.087)\end{array}$ & $\begin{array}{c}-0.034 \\
(0.089)\end{array}$ & $\begin{array}{c}0.009 \\
(0.090)\end{array}$ \\
\hline Highest track & & & $\begin{array}{l}-0.025 \\
(0.069)\end{array}$ & $\begin{array}{l}-0.036 \\
(0.069)\end{array}$ & $\begin{array}{c}0.024 \\
(0.074)\end{array}$ \\
\hline Degree of fitness $\mathrm{T} 1$ & & & & $\begin{array}{c}0.121 \\
(0.082)\end{array}$ & $\begin{array}{c}0.112 \\
(0.081)\end{array}$ \\
\hline Degree of fitness T3 & & & & $\begin{array}{c}0.045 \\
(0.077)\end{array}$ & $\begin{array}{c}0.056 \\
(0.076)\end{array}$ \\
\hline Work experience & & & & & $\begin{array}{c}0.024 * * * \\
(0.009)\end{array}$ \\
\hline Constant & $\begin{array}{c}0.544 * * * \\
(0.066)\end{array}$ & $\begin{array}{c}0.643 * * * \\
(0.079)\end{array}$ & $\begin{array}{c}0.660 * * * \\
(0.083)\end{array}$ & $\begin{array}{c}0.636^{* * * *} \\
(0.089)\end{array}$ & $\begin{array}{c}0.359 * * * \\
(0.132)\end{array}$ \\
\hline Observations & 375 & 375 & 375 & 375 & 375 \\
\hline R-squared & 0.006 & 0.105 & 0.106 & 0.113 & 0.136 \\
\hline
\end{tabular}


Table 7

Mandatory Military Service and Currently Being Married

\begin{tabular}{|c|c|c|c|c|c|}
\hline & (1) & (2) & (3) & (4) & (5) \\
\hline Treated & $\begin{array}{l}0.127 * \\
(0.074)\end{array}$ & $\begin{array}{c}0.051 \\
(0.076)\end{array}$ & $\begin{array}{c}0.073 \\
(0.074)\end{array}$ & $\begin{array}{c}0.100 \\
(0.074)\end{array}$ & $\begin{array}{c}0.097 \\
(0.073)\end{array}$ \\
\hline Age & & $\begin{array}{c}0.026 * * * \\
(0.006)\end{array}$ & $\begin{array}{c}0.027 * * * \\
(0.006)\end{array}$ & $\begin{array}{c}0.027 * * * \\
(0.006)\end{array}$ & $\begin{array}{c}0.011 \\
(0.010)\end{array}$ \\
\hline Age squared & & $\begin{array}{l}-0.003 \\
(0.002)\end{array}$ & $\begin{array}{l}-0.002 \\
(0.002)\end{array}$ & $\begin{array}{c}-0.002 \\
(0.002)\end{array}$ & $\begin{array}{c}-0.002 \\
(0.002)\end{array}$ \\
\hline Lower track & & & $\begin{array}{c}-0.181 * * \\
(0.082)\end{array}$ & $\begin{array}{c}-0.185^{* *} \\
(0.080)\end{array}$ & $\begin{array}{c}-0.181 * * \\
(0.079)\end{array}$ \\
\hline Medium track & & & $\begin{array}{c}-0.150^{*} \\
(0.084)\end{array}$ & $\begin{array}{c}-0.140^{*} \\
(0.084)\end{array}$ & $\begin{array}{l}-0.111 \\
(0.086)\end{array}$ \\
\hline Highest track & & & $\begin{array}{c}-0.127^{*} \\
(0.068)\end{array}$ & $\begin{array}{c}-0.128^{*} \\
(0.068)\end{array}$ & $\begin{array}{l}-0.087 \\
(0.072)\end{array}$ \\
\hline Degree of fitness T1 & & & & $\begin{array}{c}0.058 \\
(0.076)\end{array}$ & $\begin{array}{c}0.052 \\
(0.077)\end{array}$ \\
\hline Degree of fitness T3 & & & & $\begin{array}{c}0.147^{*} \\
(0.075)\end{array}$ & $\begin{array}{c}0.155 * * \\
(0.073)\end{array}$ \\
\hline Work experience & & & & & $\begin{array}{c}0.016^{* *} \\
(0.008)\end{array}$ \\
\hline Constant & $\begin{array}{c}0.481 * * * \\
(0.066)\end{array}$ & $\begin{array}{c}0.612 * * * \\
(0.079)\end{array}$ & $\begin{array}{c}0.685^{* * * *} \\
(0.082)\end{array}$ & $\begin{array}{c}0.630 * * * \\
(0.089)\end{array}$ & $\begin{array}{c}0.438 * * * \\
(0.130)\end{array}$ \\
\hline Observations & 375 & 375 & 375 & 375 & 375 \\
\hline R-squared & 0.012 & 0.073 & 0.095 & 0.108 & 0.118 \\
\hline
\end{tabular}


Table 8

Mandatory Military Service and Currently Living in a Partnership

\begin{tabular}{|c|c|c|c|c|c|}
\hline & (1) & (2) & (3) & (4) & (5) \\
\hline Treated & $\begin{array}{c}0.033 \\
(0.051)\end{array}$ & $\begin{array}{l}-0.010 \\
(0.052)\end{array}$ & $\begin{array}{c}-0.004 \\
(0.053)\end{array}$ & $\begin{array}{c}0.002 \\
(0.052)\end{array}$ & $\begin{array}{l}-0.001 \\
(0.048)\end{array}$ \\
\hline Age & & $\begin{array}{c}0.012 * * \\
(0.005)\end{array}$ & $\begin{array}{c}0.013 * * * \\
(0.005)\end{array}$ & $\begin{array}{c}0.012 * * * \\
(0.005)\end{array}$ & $\begin{array}{l}-0.006 \\
(0.008)\end{array}$ \\
\hline Age squared & & $\begin{array}{c}-0.004^{* *} \\
(0.001)\end{array}$ & $\begin{array}{c}-0.003 * * \\
(0.001)\end{array}$ & $\begin{array}{c}-0.003 * * \\
(0.001)\end{array}$ & $\begin{array}{c}-0.004 * * * \\
(0.001)\end{array}$ \\
\hline Lower track & & & $\begin{array}{c}-0.068 \\
(0.055)\end{array}$ & $\begin{array}{c}-0.069 \\
(0.055)\end{array}$ & $\begin{array}{c}-0.064 \\
(0.052)\end{array}$ \\
\hline Medium track & & & $\begin{array}{l}-0.104 \\
(0.068)\end{array}$ & $\begin{array}{l}-0.105 \\
(0.068)\end{array}$ & $\begin{array}{l}-0.070 \\
(0.069)\end{array}$ \\
\hline Highest track & & & $\begin{array}{l}-0.005 \\
(0.047)\end{array}$ & $\begin{array}{l}-0.009 \\
(0.047)\end{array}$ & $\begin{array}{c}0.039 \\
(0.050)\end{array}$ \\
\hline Degree of fitness T1 & & & & $\begin{array}{c}0.048 \\
(0.049)\end{array}$ & $\begin{array}{c}0.041 \\
(0.049)\end{array}$ \\
\hline Degree of fitness T3 & & & & $\begin{array}{c}0.030 \\
(0.050)\end{array}$ & $\begin{array}{c}0.039 \\
(0.049)\end{array}$ \\
\hline Work experience & & & & & $\begin{array}{c}0.019 * * * \\
(0.007)\end{array}$ \\
\hline Constant & $\begin{array}{c}0.848 * * * \\
(0.046)\end{array}$ & $\begin{array}{c}0.957 * * * \\
(0.053)\end{array}$ & $\begin{array}{c}0.981 * * * \\
(0.054)\end{array}$ & $\begin{array}{c}0.967 * * * \\
(0.056)\end{array}$ & $\begin{array}{c}0.743 * * * \\
(0.108)\end{array}$ \\
\hline Observations & 375 & 375 & 375 & 375 & 375 \\
\hline R-squared & 0.002 & 0.059 & 0.072 & 0.075 & 0.106 \\
\hline
\end{tabular}


Table 9

Mandatory Military Service and Satisfaction with Various Aspects of Life

\begin{tabular}{|c|c|c|c|c|c|c|}
\hline & $\begin{array}{l}(1) \\
\text { Life }\end{array}$ & $\begin{array}{c}(2) \\
\text { Work } \\
\end{array}$ & $\begin{array}{c}(3) \\
\text { Finances }\end{array}$ & $\begin{array}{c}(4) \\
\text { Health }\end{array}$ & $\begin{array}{c}(5) \\
\text { Family }\end{array}$ & $\begin{array}{c}(6) \\
\text { Friends }\end{array}$ \\
\hline Treated & $\begin{array}{c}0.023 \\
(0.019)\end{array}$ & $\begin{array}{c}0.055 \\
(0.037)\end{array}$ & $\begin{array}{c}0.016 \\
(0.030)\end{array}$ & $\begin{array}{l}-0.016 \\
(0.028)\end{array}$ & $\begin{array}{c}0.051 \\
(0.037)\end{array}$ & $\begin{array}{c}0.020 \\
(0.022)\end{array}$ \\
\hline Age & $\begin{array}{c}-0.007 * * \\
(0.003)\end{array}$ & $\begin{array}{l}-0.002 \\
(0.004)\end{array}$ & $\begin{array}{c}-0.007 * * \\
(0.004)\end{array}$ & $\begin{array}{l}-0.006 \\
(0.004)\end{array}$ & $\begin{array}{l}-0.007 \\
(0.005)\end{array}$ & $\begin{array}{l}-0.004 \\
(0.003)\end{array}$ \\
\hline Age squared & $\begin{array}{l}-0.000 \\
(0.000)\end{array}$ & $\begin{array}{l}-0.001 \\
(0.001)\end{array}$ & $\begin{array}{l}-0.001 \\
(0.001)\end{array}$ & $\begin{array}{l}-0.000 \\
(0.001)\end{array}$ & $\begin{array}{l}-0.000 \\
(0.001)\end{array}$ & $\begin{array}{c}0.000 \\
(0.000)\end{array}$ \\
\hline Lower track & $\begin{array}{c}-0.104 * * * \\
(0.024)\end{array}$ & $\begin{array}{c}-0.079 * * \\
(0.039)\end{array}$ & $\begin{array}{c}-0.144 * * * \\
(0.033)\end{array}$ & $\begin{array}{c}-0.073 * * \\
(0.037)\end{array}$ & $\begin{array}{l}-0.073^{*} \\
(0.040)\end{array}$ & $\begin{array}{l}-0.038 \\
(0.023)\end{array}$ \\
\hline Medium track & $\begin{array}{l}-0.008 \\
(0.025)\end{array}$ & $\begin{array}{l}-0.021 \\
(0.039)\end{array}$ & $\begin{array}{l}-0.027 \\
(0.027)\end{array}$ & $\begin{array}{l}-0.002 \\
(0.036)\end{array}$ & $\begin{array}{c}-0.093 * * \\
(0.045)\end{array}$ & $\begin{array}{l}-0.062^{*} \\
(0.032)\end{array}$ \\
\hline Highest track & $\begin{array}{l}-0.023 \\
(0.019)\end{array}$ & $\begin{array}{c}-0.066^{* *} \\
(0.028)\end{array}$ & $\begin{array}{l}-0.007 \\
(0.021)\end{array}$ & $\begin{array}{c}0.007 \\
(0.027)\end{array}$ & $\begin{array}{l}-0.023 \\
(0.031)\end{array}$ & $\begin{array}{c}-0.073 * * * \\
(0.019)\end{array}$ \\
\hline Degree of fitness T1 & $\begin{array}{l}-0.011 \\
(0.022)\end{array}$ & $\begin{array}{l}-0.041 \\
(0.033)\end{array}$ & $\begin{array}{c}0.027 \\
(0.024)\end{array}$ & $\begin{array}{l}-0.031 \\
(0.034)\end{array}$ & $\begin{array}{l}-0.037 \\
(0.044)\end{array}$ & $\begin{array}{l}-0.026 \\
(0.025)\end{array}$ \\
\hline Degree of fitness T3 & $\begin{array}{c}0.028 \\
(0.023)\end{array}$ & $\begin{array}{l}-0.017 \\
(0.034)\end{array}$ & $\begin{array}{c}0.023 \\
(0.032)\end{array}$ & $\begin{array}{l}-0.013 \\
(0.036)\end{array}$ & $\begin{array}{c}0.051 \\
(0.035)\end{array}$ & $\begin{array}{l}-0.003 \\
(0.024)\end{array}$ \\
\hline Work experience & $\begin{array}{c}0.010 * * * \\
(0.003)\end{array}$ & $\begin{array}{c}0.003 \\
(0.004)\end{array}$ & $\begin{array}{c}0.012 * * * \\
(0.003)\end{array}$ & $\begin{array}{c}0.005 \\
(0.003)\end{array}$ & $\begin{array}{c}0.009 * * \\
(0.004)\end{array}$ & $\begin{array}{c}0.002 \\
(0.002)\end{array}$ \\
\hline Constant & $\begin{array}{c}0.678 * * * \\
(0.037)\end{array}$ & $\begin{array}{c}0.722 * * * \\
(0.068)\end{array}$ & $\begin{array}{c}0.638 * * * \\
(0.051)\end{array}$ & $\begin{array}{c}0.771 * * * \\
(0.048)\end{array}$ & $\begin{array}{c}0.684 * * * \\
(0.062)\end{array}$ & $\begin{array}{c}0.817 * * * \\
(0.040)\end{array}$ \\
\hline $\begin{array}{l}\text { Observations } \\
\text { R-squared }\end{array}$ & $\begin{array}{c}375 \\
0.150\end{array}$ & $\begin{array}{c}361 \\
0.063\end{array}$ & $\begin{array}{c}375 \\
0.161\end{array}$ & $\begin{array}{c}375 \\
0.040\end{array}$ & $\begin{array}{c}374 \\
0.059\end{array}$ & $\begin{array}{c}375 \\
0.057\end{array}$ \\
\hline $\begin{array}{l}\text { Note: } \text { Robust standard er } \\
\text { satisfaction indicators is } \\
\text { estimates. } \\
\text { Life }\end{array}$ & $\begin{array}{l}\text { os in parenthe } \\
10 \text { in the origi } \\
\text { h life in gene } \\
\text { h work } \\
\text { h money, inc } \\
\text { h health } \\
\text { h family life } \\
\text { h circle of fri }\end{array}$ & ral & essions & $\begin{array}{l}\mathrm{p}<0.1 . \mathrm{T} \\
\text { lized to }[0\end{array}$ & $\begin{array}{l}\text { scale of the } \\
\text { for these }\end{array}$ & \\
\hline
\end{tabular}


Table 10

OLS Results for the Effect on Wages of Mandatory Treatment Before and After the 1995 Reform

\begin{tabular}{|c|c|c|c|c|c|c|}
\hline & \multirow{2}{*}{\multicolumn{2}{|c|}{$\begin{array}{l}\text { (1) } \\
\text { Birth cohorts } \\
1970-1975^{1}\end{array}$}} & \multirow{2}{*}{\multicolumn{2}{|c|}{$\begin{array}{l}(3) \\
\text { Birth cohorts } \\
1976-1984\end{array}$}} & \multirow{2}{*}{\multicolumn{2}{|c|}{$\begin{array}{c}\text { (5) } \\
\text { Birth cohorts } \\
\text { 1976-1984 - Treated serving } \\
\text { no longer than } 20 \text { months in } \\
\text { the military }\end{array}$}} \\
\hline & & & & & & \\
\hline Treated & $\begin{array}{c}0.086 \\
(0.088)\end{array}$ & $\begin{array}{c}0.107 \\
(0.089)\end{array}$ & $\begin{array}{c}-0.156^{* *} \\
(0.078)\end{array}$ & $\begin{array}{c}-0.151 * * \\
(0.076)\end{array}$ & $\begin{array}{l}-0.134 * \\
(0.079)\end{array}$ & $\begin{array}{l}-0.138^{*} \\
(0.078)\end{array}$ \\
\hline Age & $\begin{array}{c}0.131 \\
(0.099)\end{array}$ & $\begin{array}{c}0.119 \\
(0.098)\end{array}$ & $\begin{array}{c}0.022 \\
(0.046)\end{array}$ & $\begin{array}{l}-0.030 \\
(0.043)\end{array}$ & $\begin{array}{l}-0.000 \\
(0.045)\end{array}$ & $\begin{array}{l}-0.045 \\
(0.043)\end{array}$ \\
\hline Age squared & $\begin{array}{l}-0.015 \\
(0.012)\end{array}$ & $\begin{array}{l}-0.017 \\
(0.012)\end{array}$ & $\begin{array}{l}-0.005 \\
(0.006)\end{array}$ & $\begin{array}{l}-0.007 \\
(0.006)\end{array}$ & $\begin{array}{l}-0.008 \\
(0.007)\end{array}$ & $\begin{array}{l}-0.009 \\
(0.006)\end{array}$ \\
\hline Lower track & $\begin{array}{l}-0.207^{*} \\
(0.112)\end{array}$ & $\begin{array}{l}-0.207^{*} \\
(0.108)\end{array}$ & $\begin{array}{c}-0.272 * * \\
(0.113)\end{array}$ & $\begin{array}{c}-0.307 * * * \\
(0.101)\end{array}$ & $\begin{array}{l}-0.117 \\
(0.115)\end{array}$ & $\begin{array}{l}-0.171 \\
(0.105)\end{array}$ \\
\hline Medium track & $\begin{array}{l}0.247^{*} \\
(0.126)\end{array}$ & $\begin{array}{c}0.289 * * \\
(0.131)\end{array}$ & $\begin{array}{c}0.283 * * * \\
(0.078)\end{array}$ & $\begin{array}{c}0.320 * * * \\
(0.083)\end{array}$ & $\begin{array}{c}0.291 * * * \\
(0.079)\end{array}$ & $\begin{array}{c}0.333 * * * \\
(0.084)\end{array}$ \\
\hline Highest track & $\begin{array}{c}0.084 \\
(0.096)\end{array}$ & $\begin{array}{l}0.202^{*} \\
(0.113)\end{array}$ & $\begin{array}{c}0.256 * * * \\
(0.083)\end{array}$ & $\begin{array}{c}0.315 * * * \\
(0.082)\end{array}$ & $\begin{array}{c}0.247 * * * \\
(0.087)\end{array}$ & $\begin{array}{c}0.310 * * * \\
(0.084)\end{array}$ \\
\hline Degree of fitness $\mathrm{T} 1$ & $\begin{array}{c}0.089 \\
(0.131)\end{array}$ & $\begin{array}{c}0.066 \\
(0.131)\end{array}$ & $\begin{array}{l}-0.077 \\
(0.104)\end{array}$ & $\begin{array}{l}-0.080 \\
(0.096)\end{array}$ & $\begin{array}{l}-0.122 \\
(0.119)\end{array}$ & $\begin{array}{l}-0.130 \\
(0.109)\end{array}$ \\
\hline Degree of fitness T3 & $\begin{array}{c}0.019 \\
(0.122)\end{array}$ & $\begin{array}{c}0.020 \\
(0.119)\end{array}$ & $\begin{array}{l}-0.128 \\
(0.123)\end{array}$ & $\begin{array}{l}-0.097 \\
(0.122)\end{array}$ & $\begin{array}{l}-0.195 \\
(0.123)\end{array}$ & $\begin{array}{l}-0.179 \\
(0.118)\end{array}$ \\
\hline Work experience & & $\begin{array}{l}0.028^{*} \\
(0.015)\end{array}$ & & $\begin{array}{c}0.039 * * * \\
(0.009)\end{array}$ & & $\begin{array}{c}0.040 * * * \\
(0.010)\end{array}$ \\
\hline Constant & $\begin{array}{c}2.492 * * * \\
(0.194)\end{array}$ & $\begin{array}{c}2.092 * * * \\
(0.300)\end{array}$ & $\begin{array}{c}2.853 * * * \\
(0.100)\end{array}$ & $\begin{array}{c}2.370 * * * \\
(0.157)\end{array}$ & $\begin{array}{c}2.832 * * * \\
(0.099)\end{array}$ & $\begin{array}{c}2.348 * * * \\
(0.156)\end{array}$ \\
\hline $\begin{array}{l}\text { Observations } \\
\text { R-squared }\end{array}$ & $\begin{array}{c}142 \\
0.143\end{array}$ & $\begin{array}{c}142 \\
0.168\end{array}$ & $\begin{array}{c}148 \\
0.309\end{array}$ & $\begin{array}{c}148 \\
0.374\end{array}$ & $\begin{array}{c}130 \\
0.264\end{array}$ & $\begin{array}{c}130 \\
0.343\end{array}$ \\
\hline
\end{tabular}

Note: Robust standard errors in parentheses; *** $\mathrm{p}<0.01,{ }^{*} \mathrm{p}<0.05,{ }^{*} \mathrm{p}<0.1$

${ }^{1}$ Because the first birth cohort in 1975 was only slightly affected by the 1995 reform of military and community service, it is combined with the cohorts still affected by the old system.

Source: NEPS Starting Cohort 6 - Adults, doi:10.5157/NEPS:SC6:1.0.0; author calculations. 


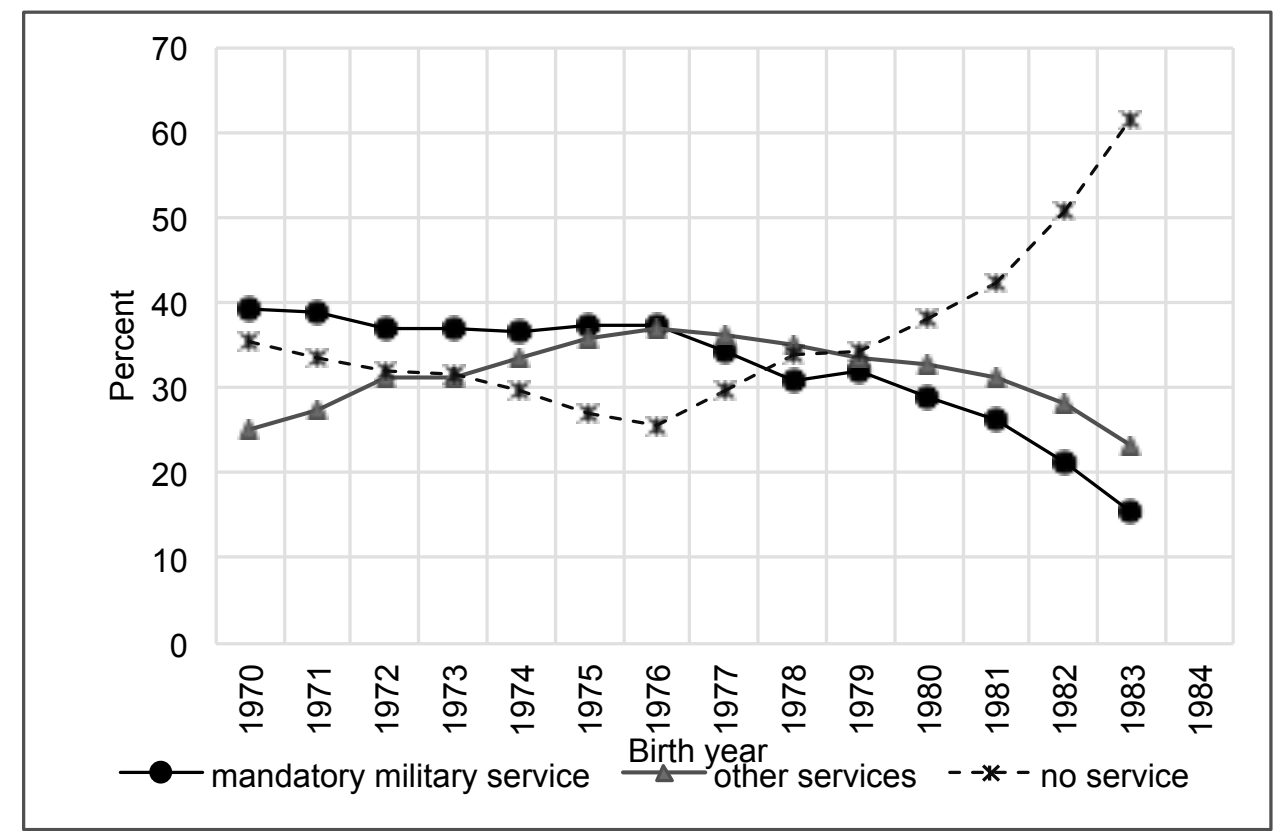

Figure 1. Share of Service Participation by Birth Year

Note: "Other services" include the community service as an alternative to the military service; this service can take various forms which are combined here. "No service" also includes several groups; for example, men not fit for service, as well as men granted an exemption from service.

Source: Tobiassen $(2001,2005)$; author calculations.

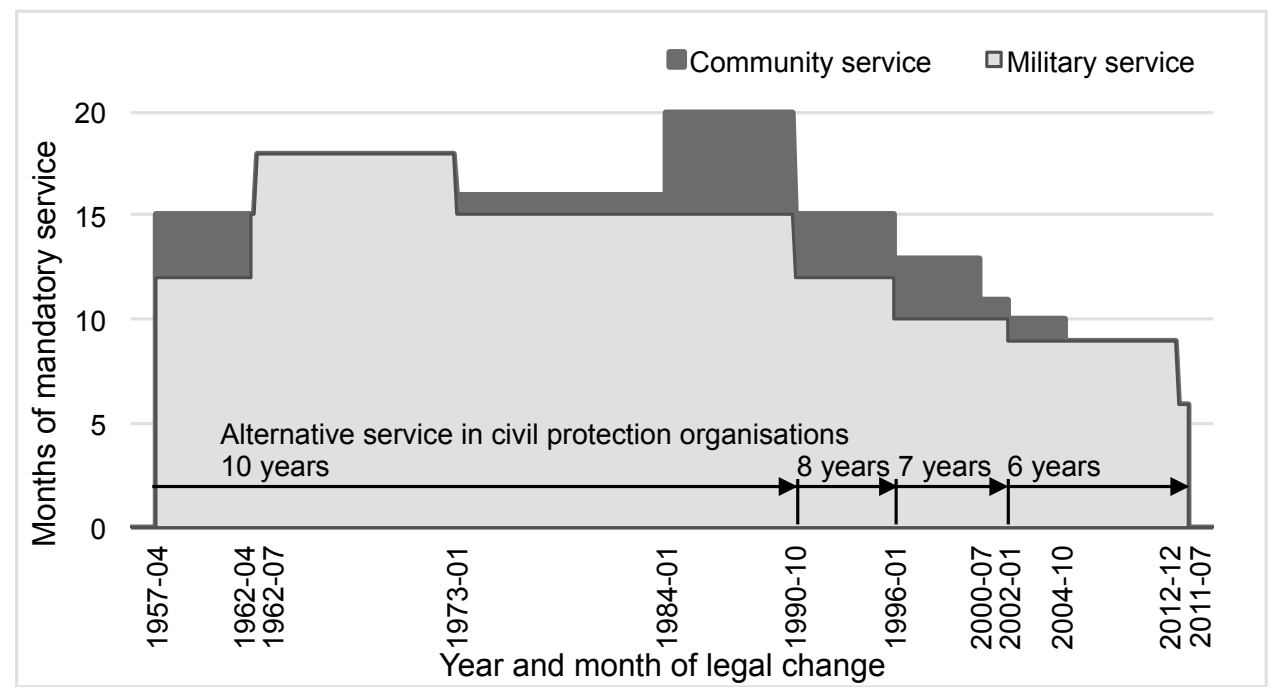

Figure 2. Duration of Mandatory Military or Community Service by Calendar Time. Source: BGB1 (1990, 1994, 1995); author illustration. 
Appendix A. - Additional Tables and Figures

Table A1

Mandatory Military Service and Wages: Estimates for Workers Having Completed the Lower Educational Track

\begin{tabular}{|c|c|c|c|c|c|}
\hline & (1) & (2) & (3) & (4) & (5) \\
\hline Treated & $\begin{array}{c}0.023 \\
(0.153)\end{array}$ & $\begin{array}{l}-0.127 \\
(0.131)\end{array}$ & $\begin{array}{l}-0.127 \\
(0.131)\end{array}$ & $\begin{array}{l}-0.114 \\
(0.155)\end{array}$ & $\begin{array}{l}-0.026 \\
(0.121)\end{array}$ \\
\hline Age & & $\begin{array}{c}0.045 * * * \\
(0.016)\end{array}$ & $\begin{array}{c}0.045^{* * *} * \\
(0.016)\end{array}$ & $\begin{array}{c}0.044 * * * \\
(0.015)\end{array}$ & $\begin{array}{l}-0.039 \\
(0.025)\end{array}$ \\
\hline Age squared & & $\begin{array}{c}-0.005 \\
(0.004)\end{array}$ & $\begin{array}{l}-0.005 \\
(0.004)\end{array}$ & $\begin{array}{l}-0.003 \\
(0.005)\end{array}$ & $\begin{array}{l}-0.004 \\
(0.004)\end{array}$ \\
\hline Degree of fitness $\mathrm{T} 1$ & & & & $\begin{array}{l}-0.212 \\
(0.189)\end{array}$ & $\begin{array}{l}-0.223 \\
(0.172)\end{array}$ \\
\hline Degree of fitness T3 & & & & $\begin{array}{c}0.166 \\
(0.181)\end{array}$ & $\begin{array}{c}0.117 \\
(0.170)\end{array}$ \\
\hline Work experience & & & & & $\begin{array}{c}0.078 * * * \\
(0.020)\end{array}$ \\
\hline Constant & $\begin{array}{c}2.434 * * * \\
(0.126)\end{array}$ & $\begin{array}{c}2.620 * * * \\
(0.136)\end{array}$ & $\begin{array}{c}2.620 * * * \\
(0.136)\end{array}$ & $\begin{array}{c}2.554 * * * \\
(0.186)\end{array}$ & $\begin{array}{c}1.529 * * * \\
(0.276)\end{array}$ \\
\hline Observations & 51 & 51 & 51 & 51 & 51 \\
\hline R-squared & 0.000 & 0.190 & 0.190 & 0.234 & 0.399 \\
\hline
\end{tabular}

Note: Robust standard errors in parentheses; *** $\mathrm{p}<0.01, * * \mathrm{p}<0.05, * \mathrm{p}<0.1$

Source: NEPS Starting Cohort 6 - Adults, doi:10.5157/NEPS:SC6:1.0.0; author calculations.

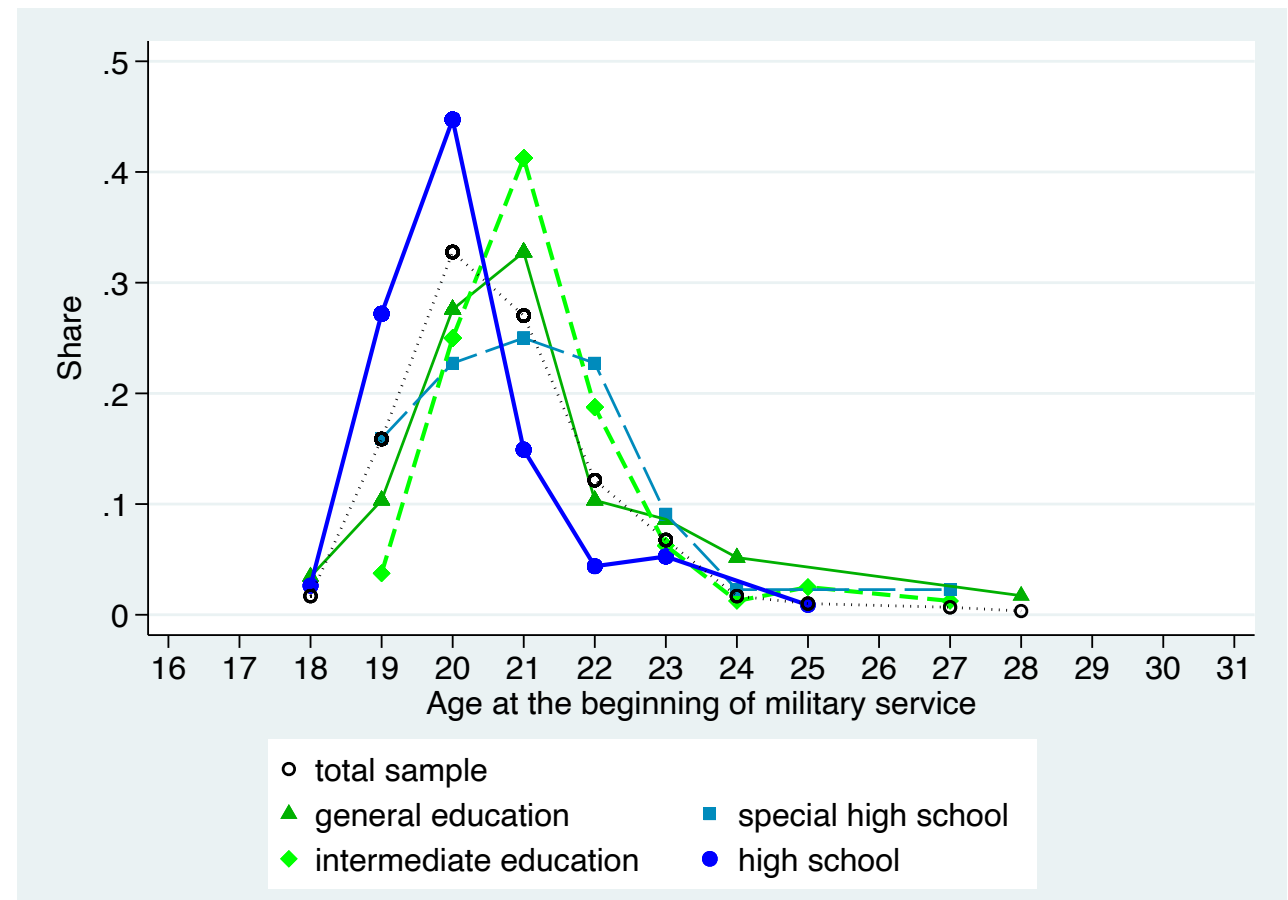

Figure A1. Distribution of Age of Beginning Mandatory Military Service by School Track Note: The graph is based on our estimation sample of 375 men with a T1 to T3 degree of fitness, some of whom were drafted and others not.

Source: NEPS Starting Cohort 6 - Adults, doi:10.5157/NEPS:SC6:1.0.0; author calculations. 


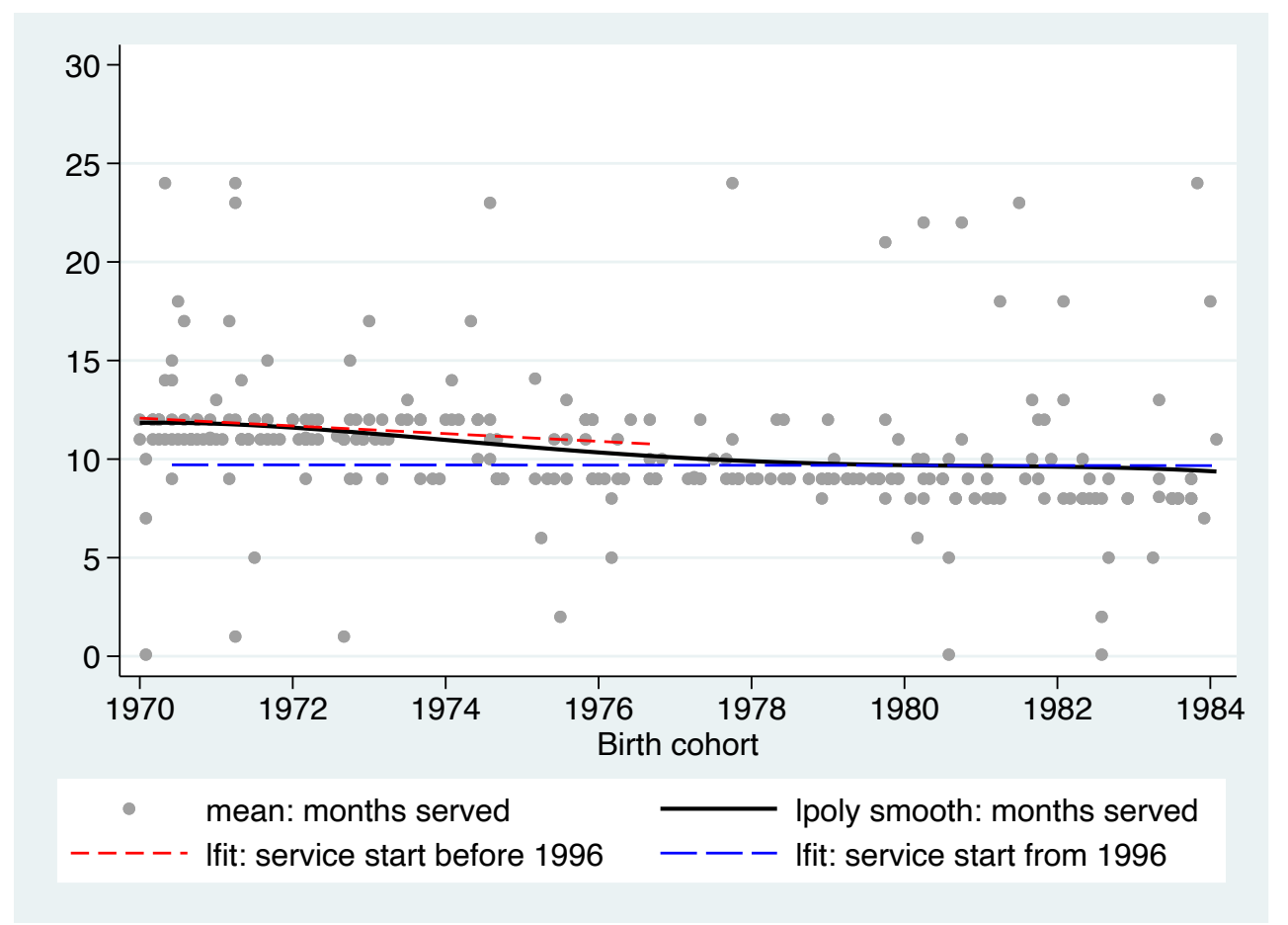

Figure A2. Duration of Military Service in Months for Men Serving Fewer than 30 Months. Source: NEPS Starting Cohort 6 - Adults, doi:10.5157/NEPS:SC6:1.0.0; author calculations.

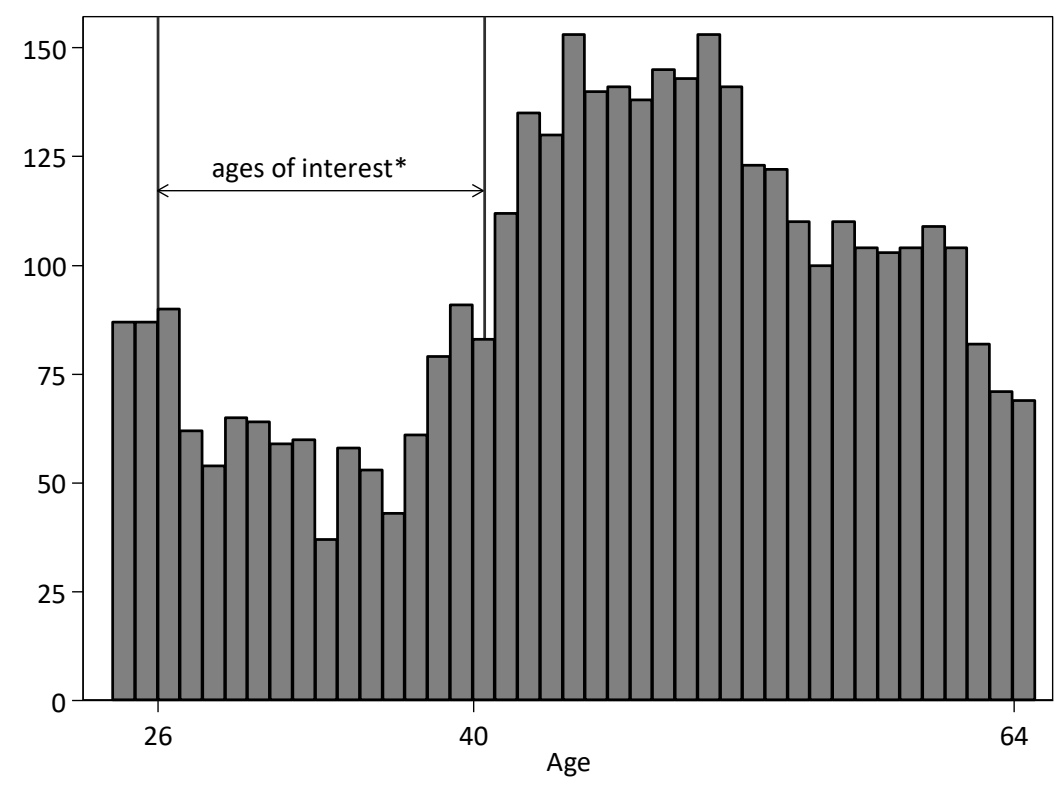

Figure A3. Number of Observations by Age.

Note: The graph is based on a sample of 3,975 men from Western Germany who were German citizens before age 20 and aged 24-64 at the time of observation; *born since 1970 and at least age 26 on the day of interview (893 observations).

Source: NEPS Starting Cohort 6 - Adults, doi:10.5157/NEPS:SC6:1.0.0; author calculations. 